haus based his advice on the fact that not all the money entailed in the bill need be spent, and also that it can be strung out over several years to minimize the impact on the budget. Nixon preferred, however, to stick to his principle of trying to hold down taxes and overrode Ruckleshaus' advice. Now that Congress has got its way, the Cuyahoga River and the Houston Ship Canal-both of which have caught fire recently - may become recreation areas by the late 1980s.

\section{LABORATORY ANIMALS}

\section{A Plague for Frogs ?}

by our Washington Correspondent

A Curious and so far unexplained ailment which killed off millions of frogs in the United States last winter and which seriously curtailed supplies of the animals for teaching and research, may be showing itself again this year. A year ago, when dealers began collecting frogs just before the hibernation season, many of them found that their animals died within a few weeks. But the phenomenon was not confined to frogs in captivity: rows of the dead animals were found in collecting ponds when the ice thawed in the Spring.

The effect of this widespread mortality was such that some supplies of frogs for teaching and embryological research dried up last winter, and preliminary indications are that the same process may be repeating itself. A large dealer in the Midwest said last week, for example, that he has already stopped buying frogs from Minnesota, which has previously been his chief source of supply, because none collected during the past week or two has survived.

But another large Midwestern dealer gave a more optimistic view of the situation. He said that he already has good frogs in hibernation which should be sufficient to meet all the demand this winter. The problem, he suggested, is confined only to certain areas in some of the midwestern states, because he has supplies from Canada, North Dakota, Minnesota and Wisconsin, and has found that with good care the frogs have gone normally into hibernation. Each year some 20 million frogs are used for teaching in the United States and about 2 million for research.

The symptoms of the ailment are that the frogs redden, which may be an indication of bacterial infection, and then die. Opinions differ on the cause of the phenomenon and so far it is still a mystery. But the United States is not the only country that is having problems with frog populations, which have been almost wiped out in parts of Great Britain during the past few years.
One theory that has been put forward is that 1970 was a particularly good spawning season, but that in the long dry summer of 1971, aquatic food was hard to find so that many animals went into hibernation in a state of malnutrition and succumbed more easily to bacterial infection. The symptoms of the ailment seem to indicate that infection of some sort is involved, but it has also been suggested that agricultural chemicals may have done the damage.

A buyer from one of the midwestern dealers pointed out last week, for example, that heavy rains fell last autumn, and again this year, increasing agricultural runoff just at the time when the frogs entered the waters to hibernate. But he said the chief evidence to implicate agricultural chemicals comes from his finding that frogs caught in September, before they entered the ponds, have hibernated normally and seem to be quite healthy, while those caught in October have died. Moreover, at a storage facility in Minnesota last year, a batch of frogs stored in hibernation in well water survived, while another batch stored in lake water died. So far, however, analyses of lake water samplès have failed to turn up evidence of excessive amounts of agricultural chemicals and in any case the bacterial infection itself could have come from the lake waters.

\section{ELECTION 1972 \\ Nixon's Friends}

by our Washington Correspondent

WITH just three weeks to go to the election, a group of scientists and engineers has been formed to work for the relection of President Nixon. Called the Science and Engineering Council in Support of the President, the group will work under the chairmanship of $\mathrm{Dr}$ William O. Baker, vice-president of Bell Laboratories Inc. and former boss of $\mathrm{Dr}$ Edward David, the President's Science Adviser. Although the council will initially take its cue from the Committee for the Reelection of the President, it was made clear last week that its presence may be felt long after November 7.

The council has entered the campaign very late in the day, and several weeks after a committee of scientists and engineers started working for Senator McGovern. But the council will be more than just a tool in the election campaign, for Dr Baker said last week that if President Nixon is reelected, it will continue to function as an independent source of advice to the Administration.

Although such functions are already being performed by a variety of organ- izations, including the Office of Science and Technology, the President's Science Advisory Committee and the National Science Board, Baker pointed out that the council's chief value would be its independence and-given that its members hold exalted positions in the scientific community notwithstanding -its ability to represent grassroots thinking. Baker added that the council is not expected to receive formal financing after the election.

So far, science and technology have not become issues in the campaign, and Baker acknowledged that there is little disagreement between the Republicans and the Democrats on the issues involving science and technology-both party platforms, for example, emphasise the need for using science and technology to help solve domestic problems. But the council has been formed to tell the American public "on behalf of scientists and engineers, the opportunities of continuing the historic commitment of the last four years in the beneficial use of scientific and technical education, research and development". When the Democrats have mentioned science and technology, however, they have suggested that the Administration's rhetoric has not been matched with dollars, and that some of the money being spent on defence and space research and development could more profitably be spent on domestic projects.

As for unemployment among scientists and engineers, Baker said last week that the situation has been "very greatly relieved". He said that the council thus supports the Administration's view that special measures to relieve unemployment among scientists and engineers are no longer needed. But Dr Vigdor Teplitz, Secretary and Treasurer of the Scientists for McGovern Committee, commented last week that his committee has found unemployment to be still a major issue among members of the scientific community and that it has not yet been solved.

Baker said last week that the council of scientists for Nixon would work chieffy by responding to requests for position papers and other matters directed to it by the Committee for the $\mathrm{Re}$. election of the President. Scientists for McGovern, on the other hand, have been concentrating on canvassing the scientific community by mail and it has also contributed to the position papers delivered by McGovern on the environment and energy.

Included among the 29-member council formed last week are Dr Simon Ramo, Dr Robert Charpie, Dr Lawrence Goldmuntz, Professor Willard Libby, Professor Richard Morse, Dr William Nierenberg, Professor Bernard Oliver, Professor S. Fred Singer, Dr Athelstan Spilhaus and Dr Edward Teller. 